\title{
CODE-SWITCHING BETWEEN THE TEACHERS AND THE STUDENTS OF THE CONVERSATION
}

\author{
Sitti Maryam Hamid \\ English Education Department, Faculty of Teacher Training and Education \\ Muhammadiyah University of Makassar \\ maryam@unismuh.ac.id
}

\begin{abstract}
This research aimed to describe code switching who used by the Teachers and the students especially kinds and functions to contribute to the interaction in conversation in the classroom. Codeswitching is an alternate use of two or more languages in the same utterance or conversation in a bilingual or multilingual conversation. Previous research has established that codeswitching can be interpreted as a resource for bilingual or multilingual children to accomplish specific communicative goals. However, codeswtiching in educational settings has not been welcomed. Previous research has reported that codeswitching in an educational context is considered as a deficit of interactional skills. To describe the functions, the researcher used a descriptive research which was conducted observation and interview. The location of this research was taken at the eighth grade students of SMAN 1 Tombolo Pao, Gowa Regency with a number of the subject were 2 teachers and 36 students. The research findings of the study showed that teachers do code-switch in the conversation in the classroom, despite their claim that they do not. The English teachers used English and Indonesian. The English teachers made code switching for (1) to make questions, (2) unpleasant feeling, (3) to strengthen request or commond, (4) repetition used for clarification reiteration of a message, (5) to give advice, (6) to create humor.. And the students used code switching to maked they are easy to speak English and easy to understand what they want to say. Switching from English to Indonesian or other languages can also be employed as communication strategy in English conversation classroom. The English teachers employ code switching to minimize either students miscomprehension on the lesson or students' difficulties in understanding the English lesson given by the English teachers in the classroom.
\end{abstract}

Keywords: Code Switching, Teacher and Students Conversation

\section{INTRODUCTION}

English is an international language; besides that English is a means of communication. English has important position in every aspect of the life

(in Irawan, 2010:1), it is not only in education but also in business, social, tourism, etc. the importance of English can be seen from other side. Nowadays many things have been writtens printed in English i.e.; magazine, newspaper, and scientific books(in Sulastri, 2008:1). 
Considering those functions of language, people study language both formal or in class and informal or outside the class. In countries where English is neither the first nor the second language, it is taught or learned as the first foreign language for practical necessary uses of communication.

In educational English has been choosen as one of the subject that should be mastered by the student; in junior high school, senior high school, and university level. In Indonesia teaching English focuses on four basic skills, namely; listening, reading, speaking and writing(curriculum, 2013) but students are hoped to be able to communicate with native speaker or people who can use English in their activities, in school the student are expected to use English actively in vocation filed, many students of enthusiastically are selfishly or thought materials mechanical way.

They were boot helped with aids or certain conversation aids that can help them to understanding the lesson, easily so the will be stick for a long time in their mind.

In order to discuss the teaching and learning of conversation, it is necessary to first describe what is meant and what is not meant by the term conversation. In (Donaldson, 2011:7) Conversation is Not a Neatly Defined Genre of Language. There is no single set of circumstances, rules, or divisions that can box up conversation, although many have tried to create classification systems that account for the wide variety of conversation types, purposes, and functions.

Conversation is a form of interactive, spontaneous communication between two or more people who are following rules of etiquette. It is polite to give and take of subjects thought of by people talking with each other for company. Conversation is Spontaneous. The lack of time to prepare a structural turn or completely pre-think a thought, along with the difficulties of an ever-changing language situation, makes conversation different from other forms of oral discourse.

Converstion is spontanious. The lack of time to prepare a structural turn or completely pre-think a thought, along with difficulties of an over-changing language situation, makes conversation different from other forms of oral discourse. 
In teaching English as foreign language in Indonesia teacher in the conversation class (in Sulastri, 2008:1) sometimes use code-switching to teach the students. In a educational setting, the use of Code-switching becomes a trend of English teachers of secondary school levels including English teachers of senior high school in SMAN 1 Ttombolo Pao Gowa Regency when they are involved in English teaching and learning process. It happens because they are familiar with at least three languages, namely Indonesian, English, and Konjonese. Indonesianin Indonesia serves as the tool of instruction of any subjects including English. English has twofold functions, namely as the target language which is learn and as a means of instruction in dealing with English language teaching. Konjonese is one of the regional languages which are also used by some English teachers of senior high schools meet some funtions.

\section{CONCEPT OF CODE-SWITCHING}

Acording to Richard (2014:1), Code-switcing is the practice of moving back and forth between two languages or between two dialects or registers of the same language.Heather (2008:1)Code-switching is the practice of moving between variations of languages in different contexts. Everyone who speaks has learned to code-switch depending on the situation and setting. In an educational context, code-switching is defined as the practice of switching between a primary and a secondary language or discourse.

In many cases, code-switching is commonly viewed with suspicion in EFL classes. Teachers and researchers in English as a second or foreign language have, on the whole, been concerned to minimize code-switching in the classroom, taking it that the switches either indicate a failure to learn the target language or an unwillingness to do so. Willis (1981:7), for instance, suggests that "if the students start speaking in their own language without your permission... it generally means that something is wrong with the lesson".

The teachers use of code switching is not always perform consciously; which means that the teacher is not always aware of the functions and outcomes of the code switching process. Therefore, in some cases it may be regarded as an 
automatic and unconscious behaviour. Nevertheless, either conscious or not, it necessarily serves some basic functions which may be beneficial in language learning environments. These functions are listed as topic switch, affective functions, and repetitive functions by Mattson and Burenhult (1999:61).

Many teachers, who are in favour of the applications of communicative techniques in the language teaching environment, oppose any form of native language use during classroom instruction. Contrary to this, supporters of the use of native language in the form of code switching, suggest that it may be an effective strategy in various aspects. Following the ideas of these two parties, some weak and strong sides of the use of code switching in foreign language classroom settings will be mentioned with a critical perspective.

Cook (2002:333) handles the subject matter considering multilingual classrooms in saying that the application of code switching in classes which do not share the same native language may create problems, as some of the students (though few in number) will somehow be neglected.In supporting the existence of code switching in language classrooms, Skiba (1997:23) suggests that in the circumstances where code switching is used due to an inability of expression, it serves for continuity in speech instead of presenting interference in language. In this respect, code switching stands to be a supporting element in communication of information and in social interaction; therefore serves for communicative purposes in the way that it is used as a tool for transference of meaning.

\section{The Conversational Structural of Code-switching and its Social and Natural Embeddednes}

From earlier and more recent research we know :

1. That code-switching is related to and indicative of group membership in particular types of bilingual speech communities, such that the regularities of the alternating use of two or more languages, within one conversation may vary to a considerable degree between speech communities, and

2. That intrasentential code-switching, where it occurs, is constrained by syntactic and morphosyntactic considerations which may or may not be of a universal kind. 
The central research question of the first type of research is how language choice reflects power and inequlity, or is an index of the rights and obligations attributed to incumbets of certain social categories. The second tradition usually adresses the question of syntactic constraints from within the framework of a particular grammatical theory (Auer, 1998:5).

In bilingual conversation, the nation of a language negotation sequence is supposed to capture all those stretches of talk in whih participants do not agree on one common language-of-interaction.

\section{The Functions of Teachers' Code Switching}

According to Hymes (1962:50), there were five basic functions about codeswitching/mixing. In the following the researcher analyzed the teacher's teaching in this course based on Hymes' framework.

(1) Expressive Functions

The teacher used code-switching to express the emotions. Chinese words are often inserted to express the true feelings.

(2) Directive Functions

Generally speaking, this function is used in a situation where a speaker wants to direct someone. This function can get the listeners' attention. In addition, this function often occurred in both social equals and social unequals. According to Hymes, there are two subcategories: (a) direction / persuasion and (b) social exclusion.

(3) Matalinguistic Functions

It includes the definition of terms, paraphrasing others' words, and some metaphors. Especially metaphors exist between equals but other functions can exist between equals and unequals.

(4) Poetic Functions

About poetic functions, it means that during the conversation, the speaker inserted some jokes, stories, some poetic quotations into an English- based conversation.

(5) Referential Functions 
According to Chen's (2003:15) explanations, referential function has following categories. The first one is terms that lack readily available in the other languages. The second one is terms that lack semantically appropriate words in other languages. The final one is that terms with which the speakers are more familiar in L1 than in L2.

The teachers' use of code switching is not always performed consciously; which means that the teacher is not always aware of the functions and outcomes of the code switching process. Therefore, in some cases it may be regarded as an automatic and unconscious behaviour. Nevertheless, either conscious or not, it necessarily serves some basic functions which may be beneficial in language learning environments. These functions are listed as topic switch, affective functions, and repetitive functions by Mattson and Burenhult (1999:61). In order to have a general idea about these, it will be appropriate to give a brief explanation about each function.

In topic switch cases, the teacher alters his/her language according to the topic that is under discussion. This is mostly observed in grammar instruction, that the teacher shifts his language to the mother tongue of his students in dealing with particular grammar points, which are taught at that moment. In these cases, the students' attention is directed to the new knowledge by making use of code switching and accordingly making use of native tongue. At this point it may be suggested that a bridge from known (native language) to unknown (new foreign language content) is constructed in order to transfer the new content and meaning is made clear in this way as it is also suggested by Cole (1998:10) "a teacher can exploit students' previous L1 learning experience to increase their understanding of L2”.

In addition to the function of code switching named as topic switch, the phenomenon also carries affective functions that serve for expression of emotions. In this respect, code switching is used by the teacher in order to build solidarity and intimate relations with the students. In this sense, one may speak off the contribution of code switching for creating a supportive language environment in the classroom. As mentioned before, this is not always a conscious process on the part of the teacher.However, one may also infer the same thing for the natural 
occurrence of code switching as one can not take into guarantee its conscious application if the Maori example given in section II is considered. Another explanation for the functionality of code switching in classroom settings is its repetitive function. In this case, the teacher uses code switching in order to transfer the necessary knowledge for the students for clarity.

Following the instruction in target language, the teacher code switches to native language in order to clarify meaning, and in this way stresses importance on the foreign language content for efficient comprehension. However, the tendency to repeat the instruction in native language may lead to some undesired student behaviours. A learner who is sure that the instruction in foreign language will be followed by a native language translation may loose interest in listening to the former instruction which will have negative academic consequences; as the student is exposed to foreign language discourse limitedly (Sert, 2005: 1).

The Functions of Students' Code Switching

As it is the case for teachers' code switching, the students also are not always aware of the reasons for code switching as well as its functions and outcomes. Although they may unconsciously perform code switching, it clearly serves some functions either beneficial or not. Eldridge names these functions as: equivalence, floor-holding, reiteration, and conflict control(Lee, 2010:8). The first function of student code switch is equivalence. In this case, the student makes use of the native equivalent of a certain lexical item in target language and therefore code switches to his/her native tongue. This process may be correlated with the deficiency in linguistic competence of target language, which makes the student use the native lexical item when he/she has not the competence for using the target language explanation for a particular lexical item. So "equivalence" functions as a defensive mechanism for students as it gives the student the opportunity to continue communication by bridging the gaps resulting from foreign language incompetence. The next function to be introduced is floorholding.

During a conversation in the target language, the students fill the stopgap with native language use. It may be suggested that this is a mechanism used by the 
students in order to avoid gaps in communication, which may result from the lack of fluency in target language. The learners performing code switching for floor holding generally have the same problem: they can not recall the appropriate target language structure or lexicon. It may be claimed that this type of language alternation may have negative effects on learning a foreign language; since it may result in loss of fluency in long term. The third consideration in students' code switching is reiteration, which is pointed by Eldridge as: messages are reinforced, emphasized, or clarified where the message has already been transmitted in one code, but not understood (Sert, 2013:4). In this case, the message in target language is repeated by the student in native tongue through which the learner tries to give the meaning by making use of a repetition technique.

The reason for this specific language alternation case may be two-folds: first, he/she may not have transferred the meaning exactly in target language. Second, the student may think that it is more appropriate to code switch in order to indicate the teacher that the content is clearly understood by him/her. The last function of students' code switching to be introduced here is conflict control. For the potentially conflictive language use of a student (meaning that the student tends to avoid a misunderstanding or tends to utter words indirectly for specific purposes), the code switching is a strategy to transfer the intended meaning. The underlying reasons for the tendency to use this type of code switching may vary according to students' needs, intentions or purposes (Mati, 2013: 10).

Additionally, the lack of some culturally equivalent lexis among the native language and target language--which may lead to violation of the transference of intended meaning--may result in code switching for conflict control; therefore possible misunderstandings are avoided.

\section{RESEARCH METHOD}

The method used in this research is descriptive qualitative method. Where the dataare described objectively or based on the fact. This method used to describe the function of use Code-switching between the teachers and the student of the conversation class and the efectiveness of use Code-switching between the teachers and the student of the conversation class.Gay (1976:189) states that 
descriptive involves collecting date in order to test hypothesis or answer concerning the current status of the subject of the study.

There are two variables in this research, namely code-switching of the conversation class and the teachers and the students.

1. Code-switching of the conversation class, is important to use for making the teachers explain about material and student easy to know about their material.

2. The teachers and the students refer to their capabilty to use codeswitching in their converastion.

The population of the research is thesecond grade at SMAN 1 Tombolo Pao in 2014/2015 academic year. There are 3 classes those are one class IPA and two class IPS. Class IPA consists of 36 members of students, IPS 1 consist of 33 members and class IPS 2 consist of 38 members of students. So the total number of students is 104 students.

In this research, the researcherused cluster random sampling, where the sample was be choosen as group rather than individuals. In determine the sample; the researcher do the following steps:

a. The researcherwrotethe name of the one class in piece of paper.

b. The researcher was roll the paper.

c. The researcherput the four papers in the glass.

d. The researcher shaked the paper and take one of them.

The instrument that was used in this research are observation and interview. Observation used to find out the how many times the teachers use code-switching in the class and how many students use code-swiching. In this way the researcherwaswrite how many times teachers and students use code switching in conversation, the reseacher also write if the teachers and the students use code switching, and the researcher also use interview to the teachers to know functions and what kinds of code switching they are used in teaching English.

\section{FINDING AND DISCUSSION}

Findings 
The finding of this study answered the problems of this research which included kinds and functions of used Code switching in conversation class. Code switching was practiced by the English teacher in order to build intimate interpersonal relationships among English teacher and students in English conversation in the classroom.

1. Result from Observation

From the observation the researcher finds functions of used code switching in conversation in the classroom by the teachers and the students.

a). First meeting on Wenesday, 21 st January 2015.

T: Good morning class.

S: Good morning Sr.

T: Ok. Hari ini kita belajar tentang( Ok. Today we will study about ) How to make Banana Juice. Ada yang tahu bagaimana cara membuat jus pisang? (Any body how to make banana juice?) D-1

Sn: Yes Sr..

T: Ok. So who can explain how to make banana juice?. Jadi siapa yang bisa menjelasakan bagaimana cara membuat jus pisang?. D-2

Sn: ramai( noisy).

T: hello what do you know about juice? yang ribut saya tunjuk('those who noisy, I point') $\mathrm{D}-3$

S1: Saya pak.( Me Sr.) Jadi, I think kita harus mempersiapkan alat dan bahannya dulu pak. ( So, I think we must be prepare tools and materials before we make juice Sr.). D-4

S2: Kalau menurut saya setelah mempersiapkan alat dan bahannya kita lanjutkan dengan mencamurkan smua bahannya ke dalam mixer. Next tuangkan juice into glass. D-5 
T: Good. Tapi lebih baik kalau kau menjelaskannya dalam bahasa Inggris.(Good. But is more than better if you explain in English). Ok any other? Ada pendapat yang lain? D-6

Sn: Diam.( Silent).

T: No more? No more? Tidak ada lagi yang bisa? Ok. karena sudah tidak ada lagi yang bisa( ok. Because no more statement), now open your book page 19 and choose one title of the five title and try to make instruction how to make it according to title who do you choose. Sekarang buka buku kalian halaman 19 dan pilih salah satu dari lima judul yang ada disitu dan buatlah cara bagaimana membuatnya sesuai dengan judul yang kalian telah pilih. D-7

b). The second Meeting on Friday, 23nd January 2015.

T: Last meeting you have homework.

Sn: ribut( noisy)

T: Please submit your homework and than find out your group. Kumpulkan tugas anda kemudian buatlah kelompok. D-8

S1: berapa orang satu kelompok pak? ( how many people of one group Sr?)D9

T: Satu kelompok terdiri dari 5 orang ( one group consist of 5 students). Masingmasing kelompok membuat satu artikel kemudian kalian diskusikan antar kelompok (each group make a article and then your discuss with another group). Understand? D-10

Sn: Yes Sr.

T: Finish? Have you finish? Ada yang sudah selesai? D-11

Sn: No Sr. Belum pak. D- 12

T: Ok. Kalau begitu selesaikan dirumah dan kita diskusikan di pertemuan berikutnya. D-13 
c). The third meeting on Saturday, 24th January 2015.

T: Bagaimana artikel kalian apakah sudah selesai?( How about your article have you finish?). D-14

Sn: Yes Sr.

T: Ok. Kita mulai dari kelompok satu untuk membacakan artikelnya and kelompok lain mengajukan pertanyaan atau pendapat( Ok. We start from the first to read his article and another group give question or suggestion). Apa judul article anda?( what is the title of your article?). D-15

S3: Global warming Sr.

T: Ok start from now.

S4: Thanks. Itulah tadi article dari kelompok kami. Any question? Ada pertanyaan? D-16

S7: can you explain why global worming dangerous for people in the world?

S2: Ok. Saya akan menjawab pertanyaan dari S7, Ok. I will answer question from S7. Jadi global warming itu berbahaya bagi manusia because suhu dibumi menjadi lebih panas dan dapat menyebabkan iritasi pada kulit manusia. D-17

S4: bagaimana dengan saudara S7?(How about you S7?) Are you accept? D18

S7: Yes.

S4: Thanks. Any question?

S23: jelaskan bagaimana cara mengurangi global warming?( Explain how to decrease global warming?). D-19

S5 : we can decrease global warming dengan mengurangi pembangunan gedung yang banyak menggunakan kaca, and decrease pembakaran hutan. D-20

S23: Ada pendapat dari yang lain?(Any suggestion from others?) D-21 
S13: I think kita juga harus mengurangi pembakaran sampah dan pembangunan pabrik yang mempunyai limbah seperti asap. D-22

S23: Ok. Thank you.

S4: Any Question? No more question?

Sn: Ribut( noisy).

$\mathrm{T}$ : ... no more ideas, anak-anak sebaiknya saya lebih bangga kepada kalian yang seharusnya membuat lima kesalahan karena menjawab lima kali, daripada kalian yang membuat nol kesalahan karena sama sekali tidak pernah menjawab, ya ('the students should, I was gladder to the students who should make five mistakes doe to answer five times rather than the students who made no mistakes because they never answer at all, yeah'). D-23

Sn: Silent.

$\mathrm{T}$ : can you see things behind the screen?

S: no, Sir.

T: I can, you must wear glasses, makanya hati-hati kalau bicara dengan orang yang berkaca mata ya?('So, be careful if you spoke with the people who was wearing glasses, yeah') D-24.

2. Result from Interview

Details on the functions of code-switching conducted by each teachers are presented in the next discussion. Interview from the teachers.

Question: What do you think about using code switching in teaching English in the classroom?

Answer : Using code-switching in teaching English very comfortable in conversation, because the students more than easy to understand and to give respon in conversation because they understand what they say. D-25

Question : How many times you used code switching in teaching English in the classroom? 
Answer : Always. In conversation, because the students easy to understand means of conversation. D-26

Question: Did you comfortable to teach in the classroom with use conversation?

Answer: Very comfortable, because students can more than easy to understand the material. D-27

Question: According to you what is the function of code switching in teaching English in the classroom?

Answer: The function of code switching is can make the students easy to understand the material. D-28

Question: How efective of using code switching in teaching English?

Answer: Code switching very efective in teaching English because the students easy to understand the material and the students can be active in learning. D-29 Question: Did you feel using code switching in teaching code switching can help you in teaching?

Answer: Yes, because with using code switching make me more than esay to give material to students and students easy to understand the material. D-30

And the data from interview for the students.

Question: When you study English, ofcourse you will get the difficult to speak your opinion. What do you do when you getting problem?

Answer: When I get difficult in speaking I used Indonesian language to make me easy to say what I want to say. D-31

Question: What is your opinion about used code switching in learning process? Are you agree?

Answer: I think the used of code switching in learning process can help us, because we can use two language. I agree. D-32

Question: Are you used code switching in learning process?

Answee: Yes always. D-33

Question: How many times you use code-switching to show your opinion in learnig process?

Answer: Always, because we get difficult to speaking English. D-34

Question: Are you happy used code switching?

Answer: Yes, because we think it is process in learning English. D-35 


\section{Discussion}

It's seen from the observation and interview, the occurrence of the code in English as foreign language instruction due to by a variety of factors relating to the purpose and the of English Teachers practice code switching. The use of more than one languages by bilingual speakers led to passage of the code are determined by a variety of causes or reasons which are related to the context of the communication situation. The reasons of the teachers and the students use code switching is:

\section{a). To Give Question}

Code switching was practiced by the English teachers because he intended to give his questions to students in English instruction in the classroom. The example from data was shown in bold and italicized forms below.

Ada yang tahu bagaimana cara membuat jus pisang? (Any body how to make banana juice?) D-1, jadi siapa yang bisa menjelaskan bagaimana cara membuat jus pisang?D-2, Ada pendapat lain?D-6, Ada yang sudah selesai?D-11, Apa judul artikel anda?D-15.

Data excerpt (D-1, D-2, D-6, D-11, and D-15) showed that the occurrence of a code of English to Indonesian was a strategy used by English teachers in order for the question that was given to the students were easier to be understood by them. This was carried out by switching from English to Indonesian as shown in as demonstrated in excerpt (D-1, D-2, D-6, D-11, and D-15).

And the students also used code switching to give question to their teachers and their friends. The example from data was shown in bold and italicized forms below.

Berapa orang dalam...?D-9, Adapertanyaan?D-16, Bagaimana dengan saudara..?D-18, Jelaskan bagaiamana cara..?D- 19, Ada pendapat dari..?D21.Data except D-9 showed that the occurrence of a code of Indonesian to English was a strategy used by the students to ask their teachers. Data excerpt (D-16, D$18, \mathrm{D}-19$, and D-21) showed that the occurrence of a code of Indonesian to English was a strategy used by students in order for the question that was given to their friends were easier to be understood by them and were easier for their own 
self.. This was carried out by switching from English to Indonesian as shown in as demonstrated in excerpt (D-16, D-18, D-19 and D-21).

b). To Unpleasant Feeling

The use of a language code by English teachers from English to Indonesian language on the data below, because the English teachers wanted to show his unpleasant feeling. The example of the reason was presented in data excerpt as shown in bold and italicized form.

...yang ribut saya tunjuk('those who noisy, I point'). D-3.

With regard to data excerpt (D-3), code switching was practiced by the English teachers in English conversation in the classroom because he wanted to show their unpleasant feeling due to their students' occurrence as shown in excerpt (D-3) line 2.

c). To Show Opinion

The use of a language code by English the students from English to Indonesian language and from Indonesian to English on the data below, because the students wanted to show their opinion. The example of the reason was presented in data excerpt as shown in bold and italicized form.

Jadi, I think kita harus mempersiapkan...D-4, Kalau menurut saya...D-5, Ok, saya akan menjawab... jadi global warming adalah...D-17, ...global warming dengan mengurangi..D-20, I think kita harus mengurangi pembakaran..D-22.

With regard to data excerpt (D-4, D-5, D-17, D-20 and D-22), code switching was practiced by the students in English conversation in the classroom because he wanted to show their opinion due to their friends' occurrence as shown in excerpt (D-4, D-5, D-17, D-20 and D-22).

d). To Repetition Used for Clarification Reiteration of a Message

The term reiteration means emphasizing the points by expressing them exactly from one language to another language. This reiteration aims to reinforce intended messages for the students. This can occur in the flow of English to Indonesian. The examples were presented in bold and italicized forms as shown in the following data excerpts.

No more? No more? Tidak ada lagi yang bisa? D-7 
Data excerpts (D-7), showed that English teachers applied code switching to reiterate words, phrases, or sentence in order to assist students to understand the presented utterances. The reiteration can be in the form of English to Indonesian as shown in excerpts (D-7) line 1. The reason for this reiteration was to help students understand what their lectures were talking about.

e). To Strengthen Request or Command

Code switching was practiced by the English teachers, in order to strengthen the request or command to students in English conversation in the classroom. The example from data was shown in bold and italicized forms below.

....sekarang buka buku kalian...D-7, kumpulkan tugas..D-8, Masing-masing kelompok membuat satu artikel kemudian kalian diskusikan...D-10 ...selesaikan dirumah dan kita diskusikan di pertemuan berikutnya.D-13.

With regard to data excerpt (D-7(line 4), D-8, D-10 and D-13),code switching was practiced by English teachers in English conversation in the classroom because he wanted to give instruction to their students' occurrence as shown in excerpt (D-7(line 4), D-8, D-10 and D-13).

f). to Give Advice

The use of code between English and Indonesian by the English teachers was intended to advice to the students. The example of the function was presented in data excerpt (D-23) as shown in bold and italicized sentence.

... no more ideas, anak-anak sebaiknya saya lebih bangga kepada kalian yang seharusnya membuat lima kesalahan karena menjawab lima kali, daripada kalian yang membuat nol kesalahan karena sama sekali tidak pernah menjawab, ya ('the students should, I was gladder to the students who should make five mistakes doe to answer five times rather than the students who made no mistakes because they never answer at all, yeah').D-23

With regard to data excerpt (D-23), code switching was practiced by the English lecturer in English instruction in the classroom because the English teachers wanted to advice to the students as shown in excerpt (D-23) line 1-4.

g). To Create Humor

Code switching was also intended to create humorous situations in order to reduce students' attension when they dealt with English lesson. The data obtained 
through classroom observations showed that English lecturers code switched from English to Indonesian to create humor. The example from data was shown in bold and italicized forms below.

I can, you must wear glasses, makanya hati-hati kalau bicara dengan orang yang berkaca mata ya?('So, be careful if you spoke with the people who was wearing glasses, yeah').D- 24.

As data excerpts (D-24), English teachers applied code switching to create humor. This was carried out by switching from English to Indonesian as shown in excerpt (D-24) line 3-4. The use of Indonesian to create humor was based on the reason that it was emotionally and culturally close to English teacher language backgrounds.

And the datafindings from interview of the teachers of SMAN 1 Tombolo pao conducted below.

The teachers of SMAN 1 Tombolo Pao said that the used of code switching is very comfortable in teaching English, because code switching can ake the students more than easy to understand of material who they are learn. It seems by from data D-25. And than the teachers of SMAN 1 Tombolo Pao also always used code switching in teaching English specially in conversation and felt very comfortable in used code switching. It is shown exceprt D-26 and D-27. In D-28 the teachers conducted the function of code switching in teaching English is code switching can make the students more than easier to understand their material and the teachers also easy to explain the material to their students. And data it shown in excerpt D-29 and D-30 the teachers of SMAN 1 Tombolo Pao conducted that the used code switching in teaching English is very efective and code switching really help his to teaching English, because code switching can make the students more than easier to understand their material and the teachers also easy to explain the material to their students.

And data from the interview for the stedunts the reseachers findings that when the students got the dificult to say something or to speaking English the students choosed to used Indonesian language. It shown in D-31. The students always used code switching when their learning English in the classroom specially in conversation. They are used code switching when their want to show 
their opinion and they also with used of code switching in learning English. It is shown in D-32, D-33 and D-34. And in D-35 the students felt happy used code switching, because when they are used code switching it really help they are to understand their study and understand what their teacher and their friends means.

Code-switching in this particular study was the alternating use of English and Bahasa Indonesia within English classes by the teachers. The subjects of this study were two English teachers of a SMAN 1 Tombolo Pao. Both of the subjects observed in this study displayed positive attitudes towards code-switching. They believed that moderate code-switching is tolerable as long as the switches do not interfere with the essential processes of the learning itself. The use of Englishonly in class was highly encouraged.

Therefore, the code that is used by English teachers in conversation class not only serves for the purpose of implication input, but also has the purpose of pedagogical. As the results of his research, (Merritt in Mujiono, 58: 2013), who found that school teachers in Kenya doing instead of code between languages to focus the attention of students, conduct a clarification as well as emphasizing the material being taught. Referring to the results of the research, that for various reasons the use of the code by the Teachers in language teaching and learning process of the SMAN1 Tombolo Pao, then the use of the code, which is the first language of the students is still very necessary. Learner motivation can be raised with the use of their first language to describe those parts of the language that it difficult to understand if the language described in English. Language and cultural differences are sharp enough among language grammar aspects of English with first language learners can be offset by a systematic explanation using a language mastered by learners. describe those parts of the language that it is difficult to understand if the language described in English. Language and cultural differences are sharp enough among language grammar aspects of English with first language learners can be offset by a systematic explanation using a language mastered by learners. 


\section{CONCLUSION}

Regarding to the findings, the results show that the English lecturers employ English,and Indonesian during English conversation in the classroom. Based on the analysis of data obtained from the participants of this study, the results reveal nine reasons for code switching practices according to beliefs of the participants. Those six reasons include (1) to make questions, (2) unpleasant feeling, (3) to strengthen request or commond, (4) repetition used for clarification reiteration of a message, (5) to give advice, (6) to create humor. And the students used code switching in conversation class to maked they esay to speak English and understand what they want to say in English.

Switching from English to Indonesian or other languages can also be employed as communication strategy in English conversation classroom. The English teachers employ code switching to minimize either students miscomprehension on the lesson or students' difficulties in understanding the English lesson given by the English teachers in the classroom.

\section{BIBLIOGRAPHY}

Ade Irawan. 2010. The Factorsthat Cause Student's Dificultiesin Comprehendthe English Reading TextoftheEight Year Studentof theState Junior High School 1 of Pagaralam. Thesis: The Universityof PGRI Palembang.

Alcnauerová, Z. (2013). Code-switching and Code-mixing as Persuasive Strategies in Advertising. Thesis:The University of Masaryk. American.

Al-Hourani, A., \& Afizah, N. (2013). Code-switching in Daily Conversation. International Journal of Social Science and Humanities Research (IJSSHR):University Sains Islam Malaysia. Malaysia. (online) Vol. 1, Issue 1, pp: (40-43), Month: October-December 2013, Retrieved from www.researchpublish.com. Accessed on July 28, 2014

Angraeni, P. (2007). Audio Lingual Teaching as an Alternative Method in Teaching Speaking. Thesis:Faculty of Language and Art Semarang State University, Indonesia.

Auer P.1999. Code-switching in Conversation. New York:Routledge. 
Doley, Rajeev K. 2013. Journals: Code-Switching At The Market Place: The Trader's Tool. Tezpur University, Assam, INDIA. (online) Retrieved from www.ajssh.leena-luna.co.jp accessed on May 28, 2014

ajssh.leena-luna.co.jpw.ajssh.leena-luna.co.jp

Fraenkel, and Wallen. 1990. How to Design and Evaluate Research in Education. America:Mc Graw-Hill, Inc.

Gordon M, and Lesley. 2003. SOSIOLINGUISTIC Method and Interpretation. Australia: Blackwell Publishing.

Heriyanto. (2013). Paper :Code-switching as the Positive Politeness Strategies in Indonesian 4th Grade Students' Conversation.(online) Vol.3, No.22, 2013. Retrieved fromhttp://www.iiste.org/journals/accessed on May 28, 2014

Ibrahim Engku, H. (2013). Code-Switching in English as a Foreign Language Classroom:Teachers' Attitudes. Journal English Language Teaching; Vol. 6, No. 7; 2013: International Islamic University Malaysia, Malaysia: Canadian Center of Science and Education. (online) Retrieved from http://dx.doi.org/10.5539/elt.v6n7p139. Accessed on July 28, 2014

Inuwa, N. (2014). Factors Motivating Code Switching Within the Social Contact of Hausa Bilinguals. IOSR Journal Of Humanities And Social Science (IOSR-JHSS): University Utara Malaysia. Malaysia. (online) Volume 19. Retrieved fromwww.iosrjournals.org Accessed on July 28, 2014

Margana. (2012). Code Switching in English Teaching Process at Senior High School in Yogyakarta Special Province. Thesis:The University of Gadjah Mada Yogyakarta.

Mati, X. (2013). Assessment, Technology and education Evaluation (ATEE) :Using Code Switching as Strategy for Bilingual Education in the Classroom.(online)Retrieved from (https://www.google.co.id/search?q=using+code+switching+as+a+strategy + for + bilingualeducation + in + the + classroom $\&$ ie $=$ utf- $8 \&$ oe $=u t f-$ $8 \&$ rls=org.mozilla:enus:official\&client=firefoxa\&channel=fflb\&gws_rd=cr\&ei=8azju470mtixu asd_icgcwAccessed on May 28, 2014 
McCathy M. 1991. Discourse Analysis for Language Teachers. New York: Cabridge University Press.

Mujiono. (2013). Code Switching in English as Foreign Language Instruction Practiced by the English Lecturers at Universities. International Journal of Linguistics ISSN 1948-54252013, Vol. 5, No. 2. University of Surakarta. Indonesia. (online) Retrieved from URL: http://dx.doi.org/10.5296/ijl.v5i2.3561. Accessed on July 02, 2014.

Lee, Wona. 2010. Codswitching as a Communicative Strategy in aKorean Heritage Language Classroom. Thesis:San Diego State University. San Diego.

Pei-Shi, W. (2013). Articles: Code-switching as a strategy use in an EFL classroom in Taiwan. University of Tamking. Taiwan. (online) Retrieved from https: //www.researchpublish.com. Accessed on July 02, 2014.

Purniati. (2006). Effectivity of Contextual Instruction With Cooperative Approach In Increasing The Students Conversation Abilityof MTs DI PI At The First Class. Thesis:The Universityof PGRI Pasuruan.

Rebekah M Donals. 2011.Teaching Foreign Language Conversation: a Conversation Norms Approch. Thesis:Faculty of California State University, Chico (online)Retreieved from http://www.teslej.org/wordpress/issues/volume8/ej30/ej30a3/.Accessed on May 28, 2014

SertO . 2005.The Internet TESL Journal:The Functions of Code Switching in ELTClassrooms(online) Vol. XI, No. 8, August 2005, Retreieved from http://iteslj.org/Articles/Sert-codeswitching. html.Accessed on May 28, 2014.

Teik Cheng, O. (2013). A Preliminary Study of Teacher Code-switching in Islamic Education Instruction. Article the English Teacher Vol. XLII (1) April 2013: Nanyang Technological University, Singapore. Singapore. (Online) Retrieved from www.iosrjournals.orgAccessed on July 28, 2014. 